\title{
Türk ve Alman Üniversitelerinde Yabancı Dil Olarak Almanca Öğretmenliği Programlarının Karşılaştırılması
}

\section{A Comparison of German Language Teaching Programs in Turkey and Germany}

\author{
Dr. Öğr. Gör. Bilal ÜSTÜN ${ }^{(i D}{ }^{1}$ Dr. Öğr. Gör. Aysel DEREGÖZÜ ${ }^{(D)}{ }_{2}$
}

\begin{abstract}
$\ddot{O} z$
Bu çalışmanın amacı, Türkiye ve Almanya'nın Almanca öğretmenliği programlarının karşılaştırılmasıdır. $\mathrm{Bu}$ amaç kapsamında, iki ülkenin Yabancı Dil Olarak Almanca Öğretmenliği programları incelenmiştir. Almanya'da ortak bir program bulunmamasından ve eyaletler arasında farklılıklar olmasindan dolayı örnek olarak PH Freiburg Üniversitesi'nde uygulanan eğitim programı esas alınmıştır. Çalışmada, doküman analizi yöntemiyle içerik analizi yapılmıştır. İçerik analizi ile Almanca öğretmenliği eğitim programları, öğrenci seçme sistemi, müfredat ve mezuniyet koşulları açısından incelenmiş, programlar arasında benzerlik ve farklılıklar irdelenmiş̧tir. İki ülkede uygulanan eğitim programlarındaki benzerliklerin yanı sıra farklılıkların olduğu tespit edilmiştir. Öğrenci seçme sisteminde farklılık, Türkiye'de merkezi sınavla öğrenci kabul edilirken, Almanya'da bireysel başvurudan kaynaklanmaktadır. Müfredatta ise, toplam Ects kredi sayısı, ders süresi ve eğitim süresi açısından farklılıkların olduğu görülmektedir. Mezuniyet koşullarında farklılık, Türkiye'de dersleri başarılı şekilde geçmek yeterli görülmesi, Almanya'da bitirme tezi ve heyet önünde ders anlatımı koşulundan kaynaklanmaktadır. Elde edilen bulgular doğrultusunda, Türkiye'de, öğrenci kabul koşullarının gözden geçirilmesi ve mezuniyet şartları arasına öğretmenlik becerilerinin ispat edilmesi koşulunun eklenmesi önerilmektedir.
\end{abstract}

Anahtar Kelimeler: Alman dili, öğretmen eğitimi, eğitim programı

Makale Türü: Araştırma

\begin{abstract}
The aim of this study is to compare German Language Teaching programs in Turkey and Germany. For this aim, the German Language Teaching programs of both countries are examined. As in Germany a national wide program for German Language Teaching is not implemented, the program of the university PH Freiburg is examined. The programs are investigated in terms of acceptance conditions, curriculum and graduation conditions. The evaluation revealed that there are similarities and differences of both programs. In terms of acceptance conditions, a national wide entrance exam is conducted in Turkey, whereas in Germany students apply individually. In terms of curriculum, there are differences regarding total Ects credit points, lesson hours and education time. In terms of graduation conditions, passing the lessons is sufficient in Turkey, whereas a final thesis is needed in Germany. It is suggested to revise acceptance and graduation conditions of German Language Teaching programs in Turkey.
\end{abstract}

Keywords: German language, teacher education, education programs

Paper Type: Research

\footnotetext{
${ }^{1}$ Nevşehir Hacı Bektaş Veli Üniversitesi, Yabancı Diller Yüksekokulu, bustun@nevsehir.edu.tr.

2̇̇̇önü Üniversitesi, Yabancı Diller Yüksekokulu, aysel.deregozu @inonu.edu.tr.
}

Atıf için (to cite): Üstün, B. \& Deregözü, A. (2021). Türk ve Alman üniversitelerinde yabancı dil olarak Almanca öğretmenliği programlarının karşılaştırılması. Afyon Kocatepe Üniversitesi Sosyal Bilimler Dergisi, 23(1), 85-96. 


\section{Giriş}

Ülkelerin gelişmişlik düzeyleri sahip oldukları etkili eğitim sistemleri ile doğru orantılı olup bu orantıda en önemli denge unsuru da öğretmenlerdir. "Bir ülkenin kalkınmasında, nitelikli insan gücünün yetiştirilmesinde, toplumdaki huzur ve sosyal barışın sağlanmasında, bireylerin sosyalleşmesi ve toplumsal hayata hazırlanmasında, toplumun kültür ve değerlerinin genç kuşaklara aktarılmasında öğretmenler başroldedirler" (Özden, 1999; akt. Karataş, 2020, s. 40). "Öğretmenler, bireyin eğitim hayatında en çok etkileşim kurulan, bireyi toplumsallaştıran, pedagojik dönüşümü gerçekleştiren ve insanların hayatında en çok etki ve iz bırakan kişiler olarak kabul edilmektedir" (Özer vd., 2016). Bu yönüyle öğretmenlik mesleğinin ileri düzeyde profesyonellik gerektirdiği söylenebilir. Alkan ve Hacıŏlu (2007; akt. Pelit ve Güçer, 2006, s. 101) öğretmenliği, "eğitim sektöründe yer alan sosyal, kültür, ekonomi, bilim ve teknoloji boyutlarına sahip, alanıyla ilgili uzmanlık ve beceriyi temel alan, mesleği ile ilgili gerekli formasyona sahip, profesyonel bir uğraşı alanı" olarak tanımlamaktadır. Erden (2005, s. 179) de öğretmenlik mesleğini Alkan ve Hacıoğlu'nu destekler nitelikte tanımlamakta, “öğretmenliğin bir meslek olarak; kültürel, ekonomik, bilimsel, sosyal ve teknolojik açılardan bilgi gerektirmesiyle birlikte özel alan bilgisi gerektiren profesyonel bir alan" olduğunu ifade etmektedir. Öğretmenliğin profesyonel bir meslek olması, maddi kaygılar güdüldüğü için yapıldığı anlamına gelmemelidir. Öğretmenlik mesleği, "Sadece ekonomik gereksinimlerin karşılanması için değil, aynı zamanda psiko-sosyal olarak gelişim ve doyum sağlamak için de sürdürülen bir uğraştır" (Yazıc1, 2009, s. 34). Bu açıdan öğretmenlerin aldıkları eğitim sadece kendi kişisel gelişimleri açısından değil, toplum açısından da oldukça önemlidir. Şişman'ın (2007) da belirttiği gibi, öğretmenlerin aldıkları eğitimin kalitesinin önemli olduğu söylenebilir.

\subsection{Tarihsel Açıdan Türkiye'de Öğretmen Yetiştirme Sistemi}

Türkiye'nin öğretmen yetiştirme sistemine bakıldığında Cumhuriyetten önce ve Cumhuriyetten sonra ikiye ayrıldığ 1 görülmektedir. Cumhuriyetten önce, "1848 yılında kurulan ilk erkek öğretmen okulu Darülmuallimin, 1869'da açılan ilk kız öğretmen okulu Darülmuallimat ve 1877 'de ise, çeşitli kurumlara nitelikli muallimler yetiştirmek üzere İstanbul'da kurulan Büyük Darülmuallimin öğretmenlik mesleğinde sistemleşmeye gidilen en önemli adımlardan” kabul edilmektedir (Akyüz, 2006; akt. Aras ve Sözen, 2012, s. 2). Cumhuriyetin ilanından sonra da öğretmen yetiştirme sistemi üzerine yeni çalışmalar yapılmıştır. Cumhuriyetin ilanı ve Türkiye Büyük Millet Meclisinin açılması ile birlikte Atatürk önderliğinde öğretmen yetiştirme politikaları değişmiş ve eğitim hizmetlerinin yürütülmesi Maarif Vekâletine verilmiştir. "Maarif Vekâleti, öğretmen yetiştirme amacı ile köy öğretmen okullarını, ana muallim mekteplerini, orta öğretmen okulu köy eğitmen kurslarını, köy enstitülerini ve köy çocuklarının yükseköğrenim görmelerini sağlayan yüksek köy enstitüleri gibi yeni kurumları kurmaya özen göstermiştir" (Bilir, 2011, s. 232). Türk eğitim sisteminde Cumhuriyetin ilanından sonra öğretmen yetiştirmeye yönelik olarak çıkarılmış kanunlardan bir tanesi de 2547 sayılı Yükseköğretim Kanunu'dur. Bu kanun ile Millî Eğitim Bakanlığına bağlı iki yıllık eğitim enstitüleri Eğitim Yüksekokullarına, dört yıllık Yükseköğretim Okulları ise Eğitim Fakültelerine dönüştürülmüştür. Kavak (1999, s. 3) bu dönüşümü, "öğretmen eğitiminin niteliğinin arttırılması ve sürekli bir iç ve diş denetim ile sistemli olarak geliştirilmesi, öğretmen eğitiminin niteliğinin güvence altına alınması, öğretmen eğitiminin hizmet sunulan kesimlere belirli standartlara dayalı olarak yürütüldüğünün güvencesinin verilmesi amacıyla gerçekleştirilmeye çalışıldığını" şeklinde ifade etmiştir.

Eğitim fakülteleri lisans düzeyinde on altı program ile kurulmuştur. Bu programlar; Okul Öncesi Öğretmenliği, Sınıf Öğretmenliği, Fen Bilgisi Öğretmenliği, İlköğretim Matematik Öğretmenliği, Sosyal Bilgiler Öğretmenliği, Türkçe Öğretmenliği, İngilizce Öğretmenliğgi, Almanca Öğretmenliği, Fransızca Öğretmenliği, Müzik Öğretmenliği, Resim Öğretmenliği, Beden Eğitimi ve Spor Öğretmenliği, Görme Engelliler Öğretmenliği, İşitme Engelliler Öğretmenliği, Zihin Engelliler Öğretmenliği ve Bilgisayar ve Öğretim Teknolojileri Öğretmenliği olarak sıralanabilir (YÖK, 1998). Öğretmenlik branşları arasında her ne kadar bir değer sıralaması 
yapılması mümkün olmasa da gelişen teknolojik imkânlar ve bu imkânlar bağlamında doğan yeni ihtiyaçlar ışığında bir önem sırası yapılabilir. Globalleşen yeni dünya düzeninde, herkesin herkese internet vasıtası ile rahatça ulaşıp iletişim kurabildiği günümüzde yabancı dil ve yabancı dil eğitiminin daha da önem kazandığı söylenebilir. Türkiye'de yabancı dil denildiğinde akla ilk olarak İngilizce gelse de tarihten gelen kuvvetli bağlar sebebi ile Almancanın İngilizceden sonra ikinci sırada yer aldığg söylenebilir. Türkiye'de Almanca öğretmenliği bölümü ilk olarak 1947 yılında açılmıştır (Altunya, 2006). Bugün ise, Türkiye'de toplam 16 üniversitede Alman Dili Eğitimi Programlarında Almanca öğretmenliği eğitimi verilmektedir.

\section{2. İlgili Araştırmalar}

Alanyazın taraması, Türkiye'deki eğitim ile Almanya'daki eğitimi kıyaslayan birçok araştırmanın yapıldığı görülmektedir. Uygun ve arkadaşları (2011) Türkiye ve Almanya arasında öğretmen eğitimi programlarındaki uygulama eğitimini; Delibaş (2007) Türkiye ile Almanya arasında biyoloji öğretmeni yetiştirme programlarını; Erdem (2010) Almanya (Bavyera Eyaleti) ve Türkiye'de coğrafya öğretmeni yetiştirilmesini; Delibaş ve Babadoğan (2009) Almanya ve Türkiye biyoloji öğretmeni yetiştirme programlarını; Aykaç ve arkadaşları (2014) Türkiye ve Almanya'daki öğretmen yetiştirme uygulamalarını; Baki ve Bektaş Baki (2016) Türkiye ve Almanya'nın ortaokul matematik öğretmeni yetiştirme programlarını ve Meriç ve Tezcan da (2005) Türkiye ve Almanya'nın fen bilgisi öğretmeni yetiştirme programlarını karşılaştıran çalışmalar yapmışlardır. Alan yazında Türkiye ile farklı ülkeler arasında da karşılaştırmalı çalışmalar yapıldı̆̆ı gözlenmiştir. Sarıboğa Alagöz (2006) Türkiye'deki ve Hollanda'daki İngilizce öğretmenliği programlarını; Ergun (2013) Türkiye ve İsviçre'deki kimya öğretmeni yetiştirme programlarını; Aldemir (2010) Türkiye ve Japonya'da İngilizce öğretmeni yetiştirme sistemlerini ve Ergun ve Ersoy (2014) ise Hollanda, Romanya ve Türkiye'deki öğretmen yetiştirme sistemlerini incelemişlerdir.

\subsection{Araştırmanın Amacı ve Araştırma Soruları}

Alan yazın taraması, Türkiye ve Almanya'da yabancı dil olarak Almanca öğretmenliği programlarının da karşılaştırılmasına ihtiyaç duyulduğunu ortaya koymaktadır. İki ülkenin Almanca öğretmenliği eğitim programlarının karşılaştırılması, ülkemizde uygulanan eğitim programına ilişkin bilgiler verecek ve Almanca öğretmenliği eğitiminde niteliğin arttırılması için, ipuçları sunacaktır. Programlar arasında benzerlik ve farklılıkların ortaya konulması ile de, programların güçlü ve zayıf yönleri açığa çıkmış olacaktır. Elde edilen bulgular doğrultusunda, ülkemizde Almanca öğretmeni eğitiminde niteliğin arttırılması için program uygulayıcılarına öneriler sunulması amaçlanmaktadır.

Bu bağlamda aşağıda yer alan araştırma sorularına cevap aranmıştır:

1. Türkiye'deki Yabancı Dil Olarak Almanca Öğretmenliği programları ile Almanya'daki PH Freiburg Üniversitesi Yabancı Dil Olarak Almanca Öğretmenliği programının öğrenci seçme sistemleri arasındaki farklılıklar ve benzerlikler nelerdir?

2. Türkiye'deki Yabancı Dil Olarak Almanca Öğretmenliği programları ile Almanya'daki PH Freiburg Üniversitesi Yabancı Dil Olarak Almanca Öğretmenliği programının müfredatları arasındaki farklılıklar ve benzerlikler nelerdir?

3. Türkiye'deki Yabancı Dil Olarak Almanca Öğretmenliği programları ile Almanya'daki PH Freiburg Üniversitesi Yabancı Dil Olarak Almanca Öğretmenliği programının mezuniyet şartları arasındaki farklıl1klar ve benzerlikler nelerdir?

\section{Yöntem}

\subsection{Araştırmanın Modeli}

$\mathrm{Bu}$ araştırma bir karşılaştırmalı eğitim araştırmasıdır. $\mathrm{Bu}$ araştırma türlerinde kullanılan değişik yaklaşımlar vardır. Bu çalışma yatay yaklaşım ile tanımlayıcı yaklaşım deseni ile 
tasarlanmıştır. "Yatay yaklaşım, karşılaştırma yapılacak ülkelerin eğitim sistemlerinin belli bir öğretim aşamasının içerdiği unsurları (örneğin öğretmen yetiştirme sistemlerinin öğrenci kabul, öğretim programı içeriği ve mezuniyet şartları gibi) karşılaştırır” (Erbilgin ve Boz, 2013, s. 160). "Tanımlayıcı yaklaşımda ise konu ile ilgili alanyazın incelenir, eğitim sistemlerinin ilkeleri ve amaçları arasındaki benzerlikler ve farklılıklar karşılaştırılır” (Ültanır, 2000; akt. Ergun, 2013, s. 120).

\subsection{Verilerin Toplanması}

$\mathrm{Bu}$ araştırmada yer alan veriler nitel araştırma yöntemlerinden doküman analizi yöntemi ile toplanmıştır. Doküman analizi, "belli bir amaca dönük olarak kaynakları bulma, okuma, not alma ve değerlendirme işlemlerini kapsar ve alternatif düşünce ve fikirlerin varlıklarının netleşmesine yardımcı olur" (Çepni, 2010; akt. Baki ve Bektaş Baki, 2016, s. 232). Yıldırım ve Şimşek (2011, s. 189) ise doküman incelemesini, "araştırılan olgular hakkında yazılı kaynakların detaylı bir şekilde analiz edilmesi” olarak tanımlamaktadır. Çalışmada ihtiyaç duyulan bilgiler detaylı bir literatür taraması yapılarak elde edilmiştir. Bu araştırmada, Türkiye ile Almanya'da Yabancı Dil Olarak Almanca Öğretmenliği programlarının öğrenci seçme sistemleri, müfredatları ve mezuniyet koşulları arasındaki benzerlikler ve farklılıklar belirlenmeye çalışılmıştır. Bu amaç doğrulusunda, Türkiye'deki veriler, Yabancı Dil Olarak Almanca Öğretmenliği programları ortak bir içeriğe sahip oldukları için Yüksek Öğretim Kurulu (YÖK) tarafından hazırlanan genel program içeriklerinden elde edilmiştir. Almanya'da ise, merkezi bir program olmadığ 1 için Yabanc1 Dil Olarak Almanca Öğretmenliği eğitimi veren PH Freiburg Üniversitesinin eğitim programlarından yararlanılmıştır (Pädagogische Hochschule Freiburg, 2009). PH Freiburg Üniversitesi, program içeriklerine kolay ulaşılabilir olmasından dolayı tercih edilmiştir. Araştırmada, iki ülkedeki öğretmen yetiştirme ve atama mevzuatları, eğitim sistemleri ve öğretmen eğitimi ile ilgili dokümanlar veri kaynağı olarak kullanılmıştır. Bu veri kaynakları konu ile ilgili yazılmış tezler, kitaplar ve bilimsel dergilerde yayımlanmış makaleler olarak sıralanabilir. Veri kaynağı olarak ayrıca Almanya ve Türkiye'deki Yabancı Dil Olarak Almanca Öğretmenliği eğitimi veren üniversitelerin ve öğretmen atamasından sorumlu kurumların resmi internet sayfalarından da yararlanılmıştır. Araştırmanın veri toplama aşamasında ulaşılabilen tüm kütüphanelerden, ilgili kurumlardan, veri tabanlarından ve ulusal ve uluslararası tüm arama motorlarından faydalanılmıştır.

\subsection{Verilerin Analizi}

Araştırmanın veri çözümlemesi yapılırken nitel araştırma yöntemlerinden, analiz sonuçlarının düzenlenmesi aşamasında ise, nicel araştırma yöntemlerinden yararlanılmıştır. Araştırma sorularına bağlı olarak Almanya ve Türkiye'de Yabancı Dil Olarak Almanca Öğretmenliği programlarının benzerliklerinin ve farklılıklarının ortaya konması amacı ile betimsel analiz yaklaşımından faydalanılmıştır. Çalışmada araştırma sorularından yola çıkılarak veri analizi için kodların ve temaların yer aldığı bir çerçeve oluşturulmuştur. Veriler bu çerçeve içerisinde değerlendirilerek iki program arasındaki benzerlikler ve farklılıklar ortaya konmaya çalışılmıştır. Çerçevede yer alan kodlar ve temalar konu ile ilgili detaylı literatür taranarak oluşturulmuştur. Nitel araştırmalarda, veriler önceden belirlenmiş kodlar kullanılarak analiz edilebilir (Miles ve Hubermann, 1994). Tablo 1'de araştırmada kullanılan kodlar ve temalar gösterilmiştir.

Tablo 1. Literatüre dayalı elde edilen kodlar ve temalar

\begin{tabular}{ll}
\hline \multicolumn{1}{c}{ Tema } & \multicolumn{1}{c}{ İlişkili Kodlar } \\
\hline Öğrenci Seçme Sistemi & Merkezi sınav, Abitur \\
\hline Müfredat & Meslek Bilgisi Dersleri, Genel Kültür Dersleri, Alan Eğitimi Dersleri \\
\hline Mezuniyet Şartları & Not ortalaması, bitirme tezi, sözlü sınav \\
\hline
\end{tabular}




\subsection{Araștırmanın Etik İzinleri}

Bu çalışmada, "Yükseköğretim Kurumları Bilimsel Araştırma ve Yayın Etik Yönergesi" esas alınarak, uyulması gereken tüm kurallara uyulmuştur. Yönergenin ikinci bölümü olan "Bilimsel Araştırma ve Yayın Etiğine Aykırı Eylemler" başlığı altında yer alan eylemlerden hiçbiri gerçekleştirilmemiştir. Çalışmanın niteliği Etik Kurul izni gerektirmediğinden, Etik Kurul onayı alınmamıştır.

\section{Bulgular}

Bu bölümde, Türkiye ve Almanya' da bulunan Yabancı Dil Olarak Almanca Öğretmenliği programları belirlenmiş temalar 1şı̆̆ında madde madde sunularak, iki program arasındaki farklılıklar ve benzerlikler ortaya konmaya çalışılmıştır.

\section{1. Öğrenci Seçme Sistemine İlișkin Bulgular}

Türkiye ve Almanya arasında, üniversitelerin öğrenci seçme sistemleri karşılaştırıldığında iki ülke arasındaki öğrenci seçme sisteminin farklılıklar gösterdiği görülmektedir. Türkiye'de öğrenciler, merkezi bir sınav sistemi ile üniversitedeki programlara yerleşmektedirler. Türkiye'de yükseköğretim programlarına alınacak öğrencilerin seçimi ve tercihlerine göre üniversitelere ve programlara yerleştirilmeleri işlemi ÖSYM (Ölçme, Seçme ve Yerleştirme Merkezi) tarafından yapılan bir dizi sınav ile gerçekleştirilmektedir. Bu sınavların genel adı YKS'dir (Yükseköğretim Kurumları Sınavı). YKS'ye ortaöğretim kurumlarının (lise veya dengi okullar, açık öğretim liseleri) son sınıfında okumakta olan öğrenciler, ortaöğretim kurumlarının son sınıflarında beklemeli durumda bulunanlar, ortaöğretim kurumlarını bitirmiş olanlar ve ortaöğrenimlerini yurt dışında tamamlayıp durumları yukarıdakilerden birine uyanlar katılabilirler (ÖSYM, 2020). YKS, üç oturumdan oluşmaktadır. Bu oturumlar TYT (Temel Yeterlilik Testi), AYT (Alan Yeterlilik Testi) ve YDT (Yabancı Dil Testi) olarak adlandırılmaktadır. Tüm öğrencilerin TYT sınavına girmeleri zorunludur. TYT sınavında öğrencilere Türkçe Testinden, Sosyal Bilimler Testinden, Temel Matematik Testinden ve Fen Bilimleri Testinden oluşan sorular sorulmaktadır. Öğrencilerden dört yıllık fakültelerde okuyabilme adına tercih yapabilmeleri için TYT sınavından en az 200 puan almaları beklenir. Bu 200 puan AYT ve YDT sınavlarının hesaplanabilmesi için bir baraj veya ön şart niteliği taşımaktadır. AYT sınavında ise öğrencilere Türk Dili ve Edebiyatından, Sosyal Bilimlerden, Matematikten ve Fen Bilimlerinden sorular sorulmaktadır. Öğrencilerden tercih etmeyi planladıkları bölümlerin puan türlerine göre soruları cevaplamaları beklenir. Bu puan türleri; SÖZ (Sözel), SAY (Sayısal) ve EA (Eşit A ğırlık)'dır. YDT sınavı ise, beş ayrı dilde yapılmaktadır. Bu diller Almanca, İngilizce, Fransızca, Arapça ve Rusçadır. Öğrenciler YDT sınavına hangi dilden girmek istediklerini sınav başvuru sırasında belirtirler. YKS puanı hesaplanırken öğrencilerin testlerden elde ettikleri puanlara bir de OBP (Ortaöğretim Başarı Puanı) eklenir. OBP, öğrencilerin ortaöğretim kurumlarından mezun olduklarında elde ettikleri başarı puanlarıdır. Ortaöğretim bitirme notları en küçüğü 250, en büyüğü 500 olmak üzere ortaöğretim başarı puanına dönüştürülür. Ortaöğretimde alınan 100 üzerinden diploma notu, 5 ile çarpılarak OBP'ye dönüştürülür. Böylece, 50 olan en düşük diploma notu için OBP 250 olurken, en yüksek 100 olan diploma notu için de OBP 500 olmaktadır (ÖSYM, 2020). Sınav sonuçları açıklandığında öğrenciler aldıkları puanlara göre okumak istedikleri üniversiteler ve bölümler için tercih yaparlar ve yine ÖSYM tarafindan merkezi olarak tercih ettikleri üniversitelere ve bölümlere puanlarına uygun bir sıralama ile yerleştirilirler.

Almanya'daki öğrenci seçme sistemi ise, Türkiye'nin öğrenci seçme sisteminden daha farklıdır. Almanya'da öğrenciler "Gymnasium" adı verilen yüksek nitelikli liselerden 13. sınıfın sonunda elde ettikleri "Abitur" diploması ile üniversitelerin eğitim almak istedikleri programlarına bireysel olarak başvuru yapmaktadırlar. Abitur diploması aynı zamanda öğrencilerin yükseköğretim olgunluk seviyesine erişim belgesidir ve "Allgemeine Hochschulreife" olarak adlandırılmaktadır. Abitur, Alman eğitim sisteminde ortaögretimden 
yükseköğretime geçişi sağlayan ve sınav sonucunda elde edilen bir lise bitirme diplomasıdır (Kuş, 2019). "Kelime anlamı "bitirmek, ayrılmak" olan Abitur, Latince "Abire" sözcüğünden ortaya çıkmış olup, Alman eğitim sisteminde ulaşılabilecek en yüksek lise diplomasıdır" (Henderson, 1964; akt. Kuş, 2019, s. 11). Gymnasium denen yüksek nitelikli liseler, ilkokullarında başarılı olan öğrencilerin öğretmenleri tarafindan yönlendirildikleri en yüksek okul türüdür. Gymnasium'ların amacı, yükseköğretim için donanımlı bireyler yetiştirmektir (Göçkan, 2019). Almanya'da Türkiye'deki gibi merkezi bir yerleştirme sistemi olmadığı için öğrenciler, Gymnasium adlı nitelikli liselerden mezun olurken elde ettikleri Abitur belgesi ile okumak istedikleri bölümlere bireysel olarak başvuru yaparak alacakları kabul mektupları ile üniversitelere kayıt yaptırmaktadırlar. Eğer tercih edilen bölüm için ayrılan kontenjan yetersiz ise, öğrenciler Abitur notlarına göre bölümlere kabul edilirler. Bu açıdan Almanya' da lisedeki not ortalamasının üniversitelere yerleşebilmek için çok önemli olduğu söylenebilir. Çalışma kapsamında yapılan araştırmalar sonucunda Türkiye'deki öğrencilerin merkezi bir sınav ve merkezi bir öğrenci yerleştirme sistemi ile; Almanya' daki öğrencilerin ise lise mezuniyet puanları ile üniversitelere bireysel başvuru yaparak yükseköğretim hayatlarına başladıkları belirlenmiştir.

\subsection{Müfredata İlişskin Bulgular}

İki ülke arasındaki Yabancı Dil Olarak Almanca Öğretmenliği programları Meslek Bilgisi Dersleri (MB), Genel Kültür Dersleri (GK) ve Alan Eğitimi Dersleri (AE) olarak üç kategoride değerlendirilmiştir. Aşağıdaki tabloda iki ülkenin Yabancı Dil Olarak Almanca Öğretmenliği müfredat programları ayrı ayrı tablolar halinde sunularak yorumlanmıştır.

Tablo 2. Türkiye'de yabancı dil olarak almanca öğretmenliği programı müfredat bulgusu

\begin{tabular}{lccccc}
\hline Ders Kategorisi & Teorik & Uygulama & $\begin{array}{c}\text { Toplam } \\
(\mathbf{T}+\mathbf{U})\end{array}$ & $\begin{array}{c}\text { AKTS } \\
\text { Müfredat İcerisindeki } \\
\text { Oranı (\%) }\end{array}$ \\
\hline Meslek Bilgisi Dersleri (MB) & 44 & 12 & 56 & 92 & $\% 34$ \\
\hline Genel Kültür Dersleri (GK) & 26 & 2 & 28 & 42 & $\% 19$ \\
\hline Alan Eğitimi Dersleri (AE) & 68 & 0 & 68 & 106 & $\% 47$ \\
\hline Toplam & 138 & 14 & 152 & 240 & $\% 100$ \\
\hline
\end{tabular}

Kaynak: YÖK, 2018

Tablo 2 incelendiğinde, Türkiye'deki Yabancı Dil Olarak Almanca Öğretmenliği programları müfredatında genel kültür derslerinin $\% 19$, meslek bilgisi derslerinin $\% 34$ ve alan eğitimi derslerinin ise \%47 oranında yer aldıkları söylenebilir. Yabanc1 Dil Olarak Almanca Öğretmenliği programlarındaki toplam 138 olan teorik ders saatinin 26 saati genel kültür derslerine, 44 saati meslek bilgisi derslerine ve 68 saati de alan eğitimi derslerine ayrılmıştır. Toplam 14 saat olan uygulama derslerinin ise, 2 saati genel kültür derslerine ayrılırken 12 saati de meslek bilgisi derslerine ayrılmıştır (Deregözü, 2020, s. 156). Alan eğitimi derslerinde uygulamalı dersler bulunmamaktadır. Sonuç olarak Türkiye'deki Yabancı Dil Olarak Almanca Öğretmenliği programlarında öğrenciler 8 dönem (4 yıl) eğitim alarak 240 AKTS puanı toplamak zorundadirlar.

Tablo 3. PH Freiburg Üniversitesi yabancı dil olarak almanca öğretmenliği programı müfredat bulgusu

\begin{tabular}{|c|c|c|c|c|c|}
\hline Ders Kategorisi & Teorik & $\begin{array}{l}\text { Uygulam } \\
\text { a }\end{array}$ & $\begin{array}{l}\text { Toplam } \\
(\mathrm{T}+\mathrm{U})\end{array}$ & AKTS & $\begin{array}{c}\text { Müfredat İçerisindeki } \\
\text { Oranı }(\%)\end{array}$ \\
\hline Meslek Bilgisi Dersleri (MB) & 26 & 4 & 30 & 66 & $\% 37$ \\
\hline Genel Kültür Dersleri (GK) & 21 & 1 & 22 & 36 & $\% 20$ \\
\hline Alan Eğitimi Dersleri (AE) & 28 & 3 & 31 & 78 & $\% 43$ \\
\hline Toplam & 75 & 8 & 83 & 180 & $\% 100$ \\
\hline
\end{tabular}

Kaynak: Pädagogische Hochschule Freiburg, 2009, s. 60- 65

Tablo 3 incelendiğinde, PH Freiburg Üniversitesindeki Yabanc1 Dil Olarak Almanca Öğretmenliği programı müfredatında genel kültür derslerinin $\% 20$, meslek bilgisi derslerinin $\% 37$ ve alan eğitimi derslerinin ise $\% 43$ oranında yer aldıkları ifade edilebilir. 75 olan toplam teorik 
ders saatinin 21 saatinin genel kültür derslerine, 26 saatinin meslek bilgisi derslerine ve 28 saatinin de alan eğitimi derslerine ayrıldığı görülmektedir. Uygulamalı derslere bakıldığında ise, toplam 8 saatin 1 saatinin genel kültür derslerine, 3 saatinin alan eğitimi derslerine ve 4 saatin de meslek bilgisi derslerine ayrıldığı söylenebilir (Pädagogische Hochschule Freiburg, 2009, s.6065). Sonuç olarak Almanya'daki PH Freiburg Üniversitesi yabancı dil olarak Almanca ögretmenliği programında öğrenciler 6 dönem (3 yıl) eğitim alarak 180 AKTS puanı toplamak zorundadırlar.

İki programın müfredatları karşılaştırıldığında benzerliklerin yanında farklılıklar da göze çarpmaktadır. İki program arasında dikkat çeken ilk farkın AKTS kredi sayısı olduğu söylenebilir. Türkiye'de Yabancı Dil Olarak Almanca Öğretmenliği eğitimi alan öğrenciler 8 dönem sonunda 240 AKTS puanı toplarken Almanya'daki PH Freiburg bölümünde öğrencilerin tamamlaması gereken AKTS puanı 180 olarak görünmektedir. Bunun sebebi Almanya'nın öğretmen yetiştirme sisteminden kaynaklanmaktadır. Almanya'daki öğretmenlik bölümleri Türkiye'deki gibi tek branşta eğitim vermemektedir. Almanya'daki üniversitelerde öğretmenlik alanında eğitim alan öğrencilerin aynı zamanda bir yandal veya çift anadal eğitimi almaları zorunludur. PH Freiburg Üniversitesinde de öğrencilerin Yabancı Dil Olarak Almanca Öğretmenliği programının yanında 60 AKTS puanı değerinde ikinci bir bölüm okumaları zorunlu tutulmaktadır. Böylece iki bölümde eğitim alan öğrenciler mezun olduklarında eşit AKTS puanları almış olmaktadırlar.

Programlar arası dikkat çeken diğer bir farklılık eğitim süreleridir. Türkiye'de eğitim alan Yabancı Dil Olarak Almanca öğretmen adaylarının Almanya'da PH Freiburg Üniversitesindeki öğretmen adaylarından 2 dönem (1 yıl) daha fazla eğitim aldıkları göze çarpmaktadır.

Programlar arası bir diğer farklılık da öğrencilerin lisans süreleri boyunca aldıkları toplam ders saatlerinde ortaya çıkmaktadır. Türkiye'de eğitim alan öğrencilerin Almanya'da eğitim alan öğrencilerden neredeyse iki katı fazla ders aldıkları görülmektedir. Burada, Türkiye'de iki dönem fazla eğitim veriliyor olması şüphesiz en etkili argümandır. Ayrıca, Türkiye'deki üniversitelerde haftalık ders saatinin Almanya'daki PH Freiburg Üniversitesinden daha yoğun olduğu sonucuna ulaşıllabilir.

İki programın öğretmenlik uygulaması derslerinde ve staj uygulamalarında da farklılıklar olduğu söylenebilir. Ögretmenlik uygulaması ve staj dersleri Meslek Bilgisi Dersleri kategorisinde yer almaktadır. Türkiye'deki programlarda öğrenciler yedinci ve sekizinci dönemlerde staj okullarına gitmektedirler. Yedinci dönemde haftada bir kez staj okullarına gözlem yapmaya giden öğrenciler ikinci dönem ise staj hocası ve dersin öğretmeninin olduğu sınıfta, hazırlamış oldukları dersi öğrencilere anlatmaktadırlar. Almanya'da ise staj dersleri daha erken başlamaktadır. Öğrenciler henüz üçüncü dönemlerinde staj okullarına giderek gözlem yaparken dördüncü dönemlerinde ders anlatmaktadırlar. Son dönemlerinde ise staj okullarındaki derslerini üniversiteden gelen bir heyet önünde anlatmaktadır. Bu aynı zamanda okulu bitirebilmek için bitirme tezinin yanı sıra gerekli olan sözlü sınav yerine geçmektedir. Dolayısıyla, Almanya'da PH Freiburg Üniversitesi'nde eğitim alan bir Almanca öğretmeni aday1 okullarda daha fazla staj yaparak daha çok öğretmenlik deneyimi kazanmaktadır. Staj süresinin fazla olmasının nedeni ise, öğretmenlik deneyiminin kazanılmasında stajın önemli bir yer edinmesinden kaynaklı olduğu düşünülebilir.

Tablolar incelendiğinde her iki ülkedeki derslerin (Meslek Bilgisi Dersleri, Genel Kültür Dersleri ve Alan Eğitimi Dersleri) oran olarak birbirine çok yakın olduğu ifade edilebilir. Buradan ders çeşitlerinin ağırlıklarının benzer olduğu sonucuna ulaşılması mümkündür.

\subsection{Mezuniyet Şartlarına İlişskin Bulgular}

İki program arasındaki mezuniyet şartları incelendiğinde benzerliklerden çok farklılıklar dikkat çekmektedir. İki program arasındaki tek ortak nokta her iki programda da öğrencilerin aldıkları tüm dersleri başarı ile vermiş olmalarıdır. Türkiye'deki programlardan mezun olabilmek için öğrencilerin not ortalamalarının 4 üzerinden en az 2 olması gerekmektedir. Bunun dışında 
mezun olmak için başka bir koşul bulunmamaktadır. Bu şartlar yerine getirildiğinde programdan mezun olunabilir.

Almanya'daki PH Freiburg Üniversitesinde ise, öğrencilerden son dönemlerinde bir bitirme tezi yazmaları beklenir. Bitirme tezinin yanında öğrencilerin üniversite tarafından görevlendirilmiş bir heyet önünde ders anlatmaları ve stajlarını bu şekilde tamamlamaları istenir. $\mathrm{Bu}$ şartlar yerine getirildiğinde programdan mezun olunarak diploma alınabilir (Pädagogische Hochschule Freiburg, 2009).

\section{Tartışma}

Bu çalışmada Türkiye ve Almanya'daki Yabancı Dil Olarak Almanca Öğretmenliği programları ögrenci seçme sistemleri, müfredat ve mezuniyet şartları temaları altında incelenerek benzerlikler ve farklılıklar ortaya konmaya çalışılmıştır. Bu kapsamda Yükseköğretim Kurulu'nun (YÖK, 2019) ortak müfredat programlarından ve PH Freiburg Üniversitesinin program içeriklerinden (Pädagogische Hochschule Freiburg, 2009) yararlanılmıştır.

Yabancı Dil Olarak Almanca Öğretmenliği programları öğrenci seçme sistemleri bağlamında karşılaştırıldığında iki ülke arasında benzerliklerden çok farklılıkların dikkat çektiği belirlenmiştir. Türkiye'deki öğrenci seçme sisteminde öğrenciler Ölçme, Seçme ve Yerleştirme Merkezi (ÖSYM) araciyla merkezi bir dizi sinava girerek ve yine elde ettikleri puanlarla merkezi olarak üniversitelere yerleştirilirken, Almanya'da ise öğrencilerin lise bitirme puanlarıyla (Abitur) üniversitelere bireysel olarak başvurdukları ortaya çıkarılmıştır. Erben Keçici (2011, s. 118) de Almanya'da öğretmen eğitimi üzerine yapmış olduğu çalışmasının sonucunda Abitur sınavına değinmekte, "öğrencilerin Almanya'da üniversite eğitimi alabilmeleri için bu diplomaya mutlaka sahip olmaları gerektiğini belirtirken öğrencilerin Abitur belgesi ile üniversitelere doğrudan kayıt yaptırabildiklerini” ifade etmektedir. Koçak (2012, s. 161) da Türk ve Alman eğitim sistemlerinde yükseköğretime geçiş sürecini incelediği çalışmasında "Almanya'daki ortaöğretim kurumlarının Türkiye'nin aksine çeşitlilik gösterdiğini, herhangi bir okulu bitiren öğrencinin üniversiteye gidemediğini, Abitur'u olan öğrencilerin üniversiteye geçiş yapabildiklerini" tespit etmiştir. Almanya'nın Bavyera Eyaleti ile Türkiye'deki öğretmen yetiştirilme sistemlerinin karşılaştırıldığı bir diğer çalışmada da Almanya'daki öğrencilerin liseyi bitirme notlarına göre üniversitelere kabul edildikleri belirlenmiştir (Erdem, 2010). Delibaş ve Babadoğan (2009) ise, yaptıkları çalışmalarında lise notuyla üniversiteye doğrudan geçişe farklı bir bakış açısıyla bakmaktalar ve Almanya'nın eğitim politikalarının her bireye kendi yetenek ve ilgi alanına göre en uygun eğitim olanağını sağlamak ilkesi üzerine kurulu olduğunu gördüklerini ifade etmişlerdir. Koçak (2012, s. 151) da konuya benzer bir yaklaşımla değinerek, "Türkiye'de ortaöğretimle yükseköğretim arasında bir kopukluğun olduğunu, yükseköğretim kurumlarına yerleştirmenin merkezi bir sınavla yapıldığını ve bunun da tartışmalara yol açtığının ileri sürüldüğünü” belirtmiştir. Türkiye'deki merkezi yerleştirme sisteminde de her ne kadar ortaöğretim başarı puanı etkili olsa da bu puan Almanya'da üniversite başvurularında kabul alabilmeye direkt etki etmektedir. Bu bilgiler 1şığında lise bitirme puanlarının Almanya'daki yükseköğretim öğrenci adayları için daha belirleyici olduğu söylenebilir. Buradan, Almanya'da eğitim alan öğrencilerin ortaöğretim aşamasında okul derslerini daha ciddiye almaları gerektiği sonucu çıkarılabilir. Ancak, Gymnasium denilen okullara giriş koşullarının diğer okul türlerine göre daha yüksek olduğu konusu da göz önünde bulundurulmalıdır. Akademik başarısı yüksek öğrenciler Gymnasium'a kabul almakta ve bu okullardan da akademik anlamda iyi bir eğitim alarak üniversitelerde eğitim almaya hak kazanmaktadır. Dolayısıyla, Almanca öğretmeni adayları da bu süreçlerden geçerek nitelikli bir şekilde yetişmekte ve mesleğe geçmektedir. Türkiye'de ise liselerden mezun olan her öğrenci, Almanca öğretmenliği programlarına girebilmek için yeterli puanı karşıladığında, eğitim almaya hak kazanmakta, farklılaştırılmış bir eğitim sürecinden geçmemektedir.

İki ülke arasındaki Yabancı Dil Olarak Almanca Öğretmenliği programları müfredat başlığı altında karşıllaştırılırken üç ana başlık 1şığında incelenmiş, benzerlikler ve farklılıklar 
ortaya konmaya çalışılmıştır. Bu bölümde dersler üç kategoride karşılaştırılmıştır. Bu kategoriler Meslek Bilgisi Dersleri, Genel Kültür Dersleri ve Alan Eğitimi Dersleridir. Türkiye'de 56 saat meslek bilgisi dersi verilmektedir. Bu 56 saatin 44 saati teorik, 12 saati ise uygulamalıdır. Bu 56 saat eğitim karşılığında öğrencilere 92 AKTS puanı verilmektedir. Meslek bilgisi dersleri toplam müfredatın \%34'ünü oluşturmaktadır.

Almanya'da ise, meslek bilgisi derslerinin 26 saati teorik, 4 saati de uygulamalı olmak üzere toplam 30 saattir. Bu 30 saat karşılığında öğrenciler 66 AKTS puanı toplamaktadırlar. Meslek bilgisi dersleri genel müfredatın \%37'sini oluşturmaktadır. Türkiye'deki genel kültür derslerine bakıldığında 26 saati teorik, 2 saati uygulamalı olmak üzere toplam 28 saattir. Bu 28 saat karşılığında öğrencilere 42 AKTS puanı verilmektedir. Genel kültür dersleri genel müfredatın \%19'unu oluşturmaktadır. Almanya'da ise, 21 saati teorik, 1 saati uygulamalı olmak üzere toplam 22 saat genel kültür dersi verilmektedir. Bu 22 saat karşılığında öğrencilere 36 AKTS puanı verilmektedir. Genel kültür dersleri genel müfredatın \%20'sini oluşturmaktadır.

Türkiye'deki alan eğitimi dersleri incelendiğinde, bu derslerin toplam 68 saat olduğu görülmektedir. Alan eğitimi derslerinin tamamı teoriktir. Öğrencilere bu 68 saat karşılığında 106 AKTS puanı verilir. Alan eğitimi dersleri genel müfredatın \%47'sini oluşturmaktadır. Almanya'da ise, alan eğitimi derslerinde toplam 31 saat vardır. Bu 31 saatin 28 saati teorik, 3 saati ise uygulamalı derslerdir. Bu 31 saat karşılığında öğrencilere 78 AKTS puanı verilmektedir. Alan eğitimi dersleri genel müfredatın \%43'ünü oluşturmaktadır. Ayrıca Almanya'da öğretmenlik eğitimi alan öğrencilerin 60 AKTS puanı değerinde ikinci bir yandal veya çift anadal eğitimi almaları beklenir. İki programın müfredatları incelendiğinde ders kategorilerinin ve oranlarının birbirine oldukça benzer olduğu sonucuna ulaşılabilir. İki müfredat arasındaki farklılığın ders saatleri arasında olduğu söylenebilir. Burada alınan toplam eğitim süresinin farklılığının etkili olduğu söylenebilir çünkü Türkiye'de öğrenciler Yabancı Dil Olarak Almanca Öğretmenliği programlarında 8 dönem eğitim alırken, Almanya'da bu eğitim süresinin 6 dönem olduğu görülmektedir.

Konuya ilişkin alanyazın incelendiğinde araştırma ile ilgili benzer ve farklı sonuçlara ulaşmış birçok çalışmaya rastlanmıştır. Bu çalışmada PH Freiburg Üniversitesinde Yabancı Dil Olarak Almanca Öğretmenliği bölümünün 6 dönem sürdüğü bilgisine ulaşılmıştır (Pädagogische Hochschule Freiburg, 2009). Erdem (2010) de yapmış olduğu çalışmanın sonucunda genel olarak üniversite eğitim süresinin Almanya'da 3 ila 5 sene arasında değiştiğini belirtmiştir. Aykaç ve arkadaşları (2014) da yapmış oldukları çalışmanın sonucunda Almanya'daki üniversite eğitim sürelerine değinerek 6 ila 8 dönem arasında mezun olunabileceğini ifade etmişlerdir. Sözen ve Çabuk (2013) ise, Türkiye, Avusturya ve Almanya öğretmen yetiştirme sistemlerini inceledikleri araştırmanın sonucunda farklı bir sonuca ulaşmış ve Almanya'da öğretmen yetiştirme programlarının en az 4,5 yıl sürdüğünü belirtmişlerdir. Bu bilginin yanlış bir bilgi olduğu elbette iddia edilemez, zira Sözen ve Çabuk'un (2013) yaptıkları çalışma Almanya'nın başka bir eyaletinde yapılmış olabilir. Almanya'da 16 farklı eyalet bulunmakta ve eyaletlerdeki eğitim sistemleri ve süreleri birbirlerinden farklılık gösterebilmektedir. Çalışmada Almanya'da eğitim alan öğrencilerin ikinci bir branş eğitimi almaları gerektiği belirtilirken Baki ve Bektaş Baki (2016) de yapmış oldukları çalışmada Türkiye'deki öğretmen adaylarının yalnızca bir alanda uzmanlaştıklarını, Almanya'daki öğretmen adaylarının ise, Almanca öğretmenliğinin yanı sıra seçmiş oldukları diğer bir programdan eğitim almalarının zorunlu olduğu ve iki programda eğitim alarak uzmanlaştıklarını belirtmişlerdir. Çalışmada Türkiye'deki eğitim programlarının Almanya'daki eğitim programlarına göre daha yoğun olduğu belirlenmiştir. Erdem (2010) de çalışmasında Türkiye'de eğitim veren fakültelerin ders sayılarının ve ders programlarının oldukça yoğun olduğunu ifade etmektedir ve branş öğretmenlerinin tek bir alanda konuları bu kadar derinlemesine öğrenmek yerine iki branşta eğitim almaları gerektiğini savunmaktadır. Aykaç ve arkadaşları (2014) da Türkiye'de ve bazı Avrupa Birliği ülkelerindeki öğretmen yetiştirme uygulamalarını karşılaştırmalı olarak inceledikleri çalışmalarında öğretmenlik uygulamaları ve staj süreleri açısından öğretmen adaylarına en az uygulama imkânı veren ülkenin 1 yıl ile Türkiye 
olduğunu belirlemişlerdir. Bu çalışmada da Aykaç ve arkadaşlarını doğrular nitelikte sonuçlara ulaşılmıştır. Çalışmada Almanya'da, PH Freiburg Üniversitesinde eğitim alan öğretmen adaylarının 3 dönem öğretmenlik uygulaması dersi aldıkları belirtilmiştir. Baki ve Bektaş Baki (2013) de bu konuda benzer bir yaklaşım sergilemektedirler. Yaptıkları çalışmanın sonucunda Türkiye'de derslerin çoğunlukla kuramsal olarak işlendiği için, Almanya'dan daha fazla alan dersi alan Türk öğrencilerin öğretmenliğe daha az hazır olarak başladıklarını ifade etmişlerdir.

İki program arasındaki mezuniyet şartlarına bakıldığında Türkiye'de eğitim alan öğrencilerin mezun olabilmeleri için gerekli not ortalamasını sağlamaları gerektiği görülmektedir. Bu not ortalamas 4,00 üzerinden 2,00 olarak belirlenmiştir. Baki ve Bektaş Baki (2013) de Türkiye'de 20 krediyi tamamlayan ve not ortalaması 2,00' ın üzerinde olan öğretmen adaylarının başka bir mezuniyet sınavı uygulaması bulunmadan mezun edildiklerini söylemektedirler. Almanya'da ise öğrenciler mezun olabilmek için hem bitirme tezi yazmaları hem de bir sözlü sınavı başarı ile tamamlamaları gerekmektedir. Buradan, Almanya'daki mezuniyet şartlarının Türkiye'dekinden daha zor olduğu sonucuna ulaşılabilir.

\section{Sonuç ve Öneriler}

Sonuç olarak, Türkiye'deki Yabancı Dil Olarak Almanca Öğretmenliği programlarındaki uygulamalı derslerin artırılmasının (Deregözü, 2020, s. 159) ve mezuniyet şartlarının gözden geçirilmesinin yerinde olacağı düşünülmektedir. Mezuniyet şartı olarak genel not ortalamasının yeterli olmadığı, öğrencilerin öğretmenlik becerilerini ispat edebilecekleri sözlü bir sınava girerek mezun olmaya hak kazanmalarının daha uygun olacağı düşünülmektedir. Böylece öğretmen niteliği taşımayan öğrencilerin sisteme girmelerinin engellenebileceği öngörülmektedir. Bu çalışmada Türkiye ve Almanya'da Yabancı Dil Olarak Almanca Öğretmenliği programları karşılıklı olarak incelenerek benzerlikleri ve farklılıkları ortaya konmaya çalışılmıştır. Gelecekte yapılacak olan çalışmalarda ülkemiz eğitim sistemine 1ş1k tutabilecek bulguların elde edilmesi amacıyla, farklı bölümlerin ve ülkelerin eğitim programlarının karşılaştırılması önerilmektedir.

\section{Kaynakça}

Aldemir, A. Y. (2010). Türkiye ve Japonya'da İngilizce Öğretmeni Yetiştirme Sistemlerinin Karşılaştırılması (Yayımlanmamış yüksek lisans tezi). Balıkesir Üniversitesi Sosyal Bilimler Enstitüsü, Balıkesir.

Altunya, N. (2006). Gazi Eğitim Enstitüsü 1926-1980. Ankara: Gazi Üniversitesi Yayınları.

Aras, S. \& Sözen, S. (2012). Türkiye, Finlandiya ve Güney Kore'de öğretmen yetiştirme programlarının incelenmesi. https://docplayer.biz.tr/16179222-Turkiye-finlandiya-ve-guneykore-de-ogretmen-yetistirme-programlarinin-incelenmesi.html $\quad 19.12 .2020$ tarihinde erişilmiştir.

Aykaç, N., Kabaran, H., \& Bilgin, H. (2014). Türkiye ve bazı Avrupa Birliği ülkelerindeki öğretmen yetiştirme uygulamalarının karşılaştırmalı olarak incelenmesi (Almanya, Finlandiya, Fransa, İngiltere ve Türkiye Örneği). Turkish Studies, 9(3), 279-292.

Baki, A. \& Bektaş Baki, B. (2016). Türkiye ve Almanya’nın ortaokul Matematik Öğretmeni yetiştirme programlarının karşılaştırılması. Türk Bilgisayar ve Matematik Eğitimi Dergisi, 7(1), 229-239.

Bilir, A. (2011). Türkiye'de öğretmen yetiştirmenin tarihsel evrimi ve istihdam politikaları. Ankara Üniversitesi Ĕgitim Bilimleri Fakültesi Dergisi, 44(2), 223-246.

Çepni, S. (2010). Araştırma ve Proje Çalışmalarına Giriş. Trabzon: Celepler Matbaacılık.

Delibaş, H. \& Babadoğan, C. (2009). Almanya, İngiltere ve Türkiye Biyoloji Öğretmeni yetiştirme programlarının karşılaştırılması. Ilköğretim Online, 8(2), 556-566. 
Delibaş, H. (2007). Türkiye, İngiltere, Almanya ve Finlandiya biyoloji öğretmeni yetiştirme programlarının karşılaşstıılması (Yayımlanmamış yüksek lisans tezi). Ankara Üniversitesi Eğitim Bilimleri Enstitüsü, Ankara.

Deregözü, A. (2020). Geçmişten günümüze Almanca Öğretmenliği lisans programlarına ilişkin karşılaştırmalı bir çalışma. Diyalog Interkulturelle Zeitschrift für Germanistik. Özel Sayl, 85 Jahre Germanistik in der Türkei, 143-161.

Erben Kesici, S. (2011). Almanya'da öğretmen eğitimi. Marmara Üniversitesi Atatürk Eğitim Fakültesi Eğitim Bilimleri Dergisi, 34, 117-132.

Erbilgin, E. \& Boz, B. (2013). Matematik öğretmeni yetiştirme programlarımızın Finlandiya, Japonya ve Singapur programları ile karşılaştırılması. Hacettepe Üniversitesi Eğitim Fakültesi Dergisi, (1), 156-170.

Erdem, B. (2010). Almanya (Bavyera Eyaleti) ve Türkiye'de coğrafya öğretmeni yetiştirilmesinin karşılaşstırılması (Yayımlanmamış yüksek lisans tezi). Dokuz Eylül Üniversitesi Eğitim Bilimleri Enstitüsü, İzmir.

Erden, M. (2005). Öğretmenlik Mesleğine Giriş. İstanbul: Epsilon Yayıncılık.

Ergun, M. \& Ersoy, Ö. (2014). Hollanda, Romanya ve Türkiye'deki sınıf öğretmeni yetiştirme sistemlerinin karşılaştırılması. Kastamonu Eğitim Dergisi, 22(2), 673-700.

Ergun, M. (2013). İsviçre ve Türkiye kimya öğretmeni yetiştirme programlarının karşılaştırılması. Journal of Turkish Science Education, 10(1), 118-138.

Göçkan, A. (2019). Türk eğitim sistemi ile Alman eğitim sisteminde kademeler arası geçişlerin karşıllaştırılması (Yayımlanmamış yüksek lisans tezi). Çanakkale Onsekiz Mart Üniversitesi Eğitim Bilimleri Enstitüsü, Çanakkale.

Gürkan, T. (2007). Öğretmen nitelikleri, görev ve sorumlulukları. Okul Öncesi Eğitimde Güncel Konular, 124-137.

Karataş, K. (2020). Öğretmenlik mesleğine kuramsal bir bakış. Elektronik Eğitim Bilimleri Dergisi, 9(17), 39-56.

Kavak, Y. (1999). Öğretmen eğitiminde yeni bir yaklaşıma doğru: Standartlar ve akreditasyon. Kuram ve Uygulamada Eğitim Yönetimi Dergisi, 5(3), 313-324.

Koçak, M. (2012). Türk ve Alman eğitim sistemlerinde yükseköğretime geçiş süreci. The Journal of Language and Linguistic Studies, 8(1), 148-167.

Kuş, M. (2019). Türkiye'de uygulanan Abitur programlarının değerlendirilmesi: Bir durum çalışması (Yayımlanmamış doktora tezi). Yıldız Teknik Üniversitesi Sosyal Bilimler Enstitüsü, İstanbul.

Meriç, G. \& Tezcan, R. (2005). Fen bilgisi öğretmeni yetiştirme programlarının örnek ülkeler kapsamında değerlendirilmesi (Türkiye, Japonya, Amerika ve İngiltere örnekleri). Balıkesir Üniversitesi Fen Bilimleri Enstitüsü Dergisi, 7(1), 62-82.

Miles, M. \& Hubermann, A. M. (1994). Qualitative Data Analysis. Thousand Oaks: SAGE.

ÖSYM. (2020). 2020 Yükseköğretim Kurumları Sinavı (YKS) Kılavuzu. Ankara: ÖSYM.

Özden, Y. (1999). Ĕgitimde dönüşüm, eğitimde yeni değerler. Ankara: Pegem A Yayınc1lık.

Özer, B., Gelen, İ., Alkan Hızlı, S., Çınar, G., ve Duran, V. (2016). The most common mistakes of teacher trainees former teachers. Universal Journal of Educational Resarch, 4(5), 963-972.

Pädagogische Hochschule Freiburg (2009). Studien- und Prüfungsordnung der Pädagogischen Hochschule Freiburg für Bachelor- Studiengänge. https://www.ph- 
freiburg.de/fileadmin/dateien/fakultaet3/gesundheitspaedagogik/Studien_und_Pr\%C3\%BCfungsordnung_2009.pdf (Erişim tarihi:21.12.2020).

Pelit, E. \& Güçer, E. (2006). Öğretmen adaylarının öğretmenlik mesleği ile ilgili etik olmayan davranışlara ve öğretmenleri etik dışı davranışa yönelten faktörlere ilişkin algılamaları. Ticaret ve Turizm Eğitimi Fakültesi Dergisi, 2, 95-119.

Sarıboğa Alagöz, N. (2006). Türkiye'deki ve Hollanda'daki Ingilizce Öğretmenliği Programlarının Karşılaş̧ırılması (Yayımlanmamış yüksek lisans tezi). Anadolu Ü̉niversitesi Eğitim Bilimleri Enstitüsü, Eskişehir.

Sözen, S.\& Çabuk, A. (2013). Türkiye, Avusturya ve Almanya öğretmen yetiştirme sistemlerinin incelenmesi. Uşak Üniversitesi Sosyal Bilimler Dergisi, Özel Sayı, 213-230.

Şişman, M. (2007). Eğitim bilimlerine giriş. Ankara: Pegem A Yayıncılık.

Uygun, S., Ergen, G. ve Öztürk, İ. H. (2011). Türkiye, Almanya ve Fransa'da öğretmen eğitimi programlarında uygulama eğitiminin karşılaştırılması. Elementary Education Online, 10(2), 389-405.

Ültanır, G. (2000). Karşılaştırmalı eğitim bilimi. Ankara: Eylül Kitabevi.

Yazıcı, H. (2009). Öğretmenlik mesleği, motivasyon kaynakları ve temel tutumlar: Kuramsal bir bakış. Kastamonu Eğitim Dergisi, 17(1), 33-46.

Yıldırım, A. \& Şimşek, H. (2011). Sosyal bilimlerde nitel araştırma yöntemleri. Ankara: Seçkin Yayıncilik.

YÖK (1998). Eğitim fakültesi öğretmen yetiştirme lisans programları. Ankara: YÖK.

YÖK (2018). Yeni öğretmen yetiştirme lisans programları. https://www.yok.gov.tr/ kurumsal/idari birimler/egitim-ogretim-dairesi/yeni-ogretmen yetistirme-lisans-programlari (Erişim tarihi:18.05.2019) .

ETIKK ve BİLIMSEL İLKELER SORUMLULUK BEYANI

$\mathrm{Bu}$ çalışmanın tüm hazırlanma süreçlerinde etik kurallara ve bilimsel atıf gösterme ilkelerine riayet edildiğini yazar(lar) beyan eder. Aksi bir durumun tespiti halinde Afyon Kocatepe Üniversitesi Sosyal Bilimler Dergisi'nin hiçbir sorumluluğu olmayıp, tüm sorumluluk makale yazarlarına aittir.

\section{ARAŞTIRMACILARIN MAKALEYE KATKI ORANI BEYANI}

1. yazar katk1 oran1: $\% 50$

2. yazar katk1 oranı: $\% 50$ 